\title{
Agger nasi mucocele cause nasolacrimal duct obstruction and chronic dacryocystitis: clinical profile, management and outcome
}

\author{
Athanasios Saratziotis (1) , ${ }^{1}$ Claudia Zanotti, ${ }^{2}$ Jiannis Hajiioannou, ${ }^{3}$ Enzo Emanuelli ${ }^{2}$
}

${ }^{1}$ Department of OtolaryngologyHead and Neck Surgery, General University Hospital of Larissa, Larissa, Greece

2Department of Neurosciences, Faculty of Medicine and Surgery University of Padova, Padova, Italy

${ }^{3}$ Faculty of Medicine School, Department of Head and Neck Surgery, University Hospital of Larissa, Larissa, Greece

Correspondence to Dr Athanasios Saratziotis; asaratziotis@gmail.com

Accepted 1 May 2021

Check for updates

(c) BMJ Publishing Group Limited 2021. No commercial re-use. See rights and permissions. Published by BMJ.

To cite: Saratziotis $A$ Zanotti C, Hajiioannou J, et al. BMJ Case Rep

2021:14:e242140.

doi:10.1136/bcr-2021.

242140

\section{SUMMARY}

Epiphora is the first symptom of acquired nasolacrimal duct obstruction (NLDO), which may be due to various causes, including paranasal sinuses and tumours of the nasal cavity. A 28-year-old male patient presented chronic dacryocystitis with left-sided epiphora.

Endoscopically, a bulging of the lateral nasal wall at the left-sided agger nasi area was noted. Imaging studies (CT and MRI) revealed a left-sided giant agger nasi mucocele. An endonasal endoscopic dacryocystorhinostomy (DCR) as well as opening of the agger nasi cell with mucocele removal and anterior ethmoidectomy was performed. Based on the literature, intranasal causes have very often occurred in patients with chronic dacryocystitis, but not reported as the cause of inflammation in the mucocele of agger nasi. Identification and recognition of this endonasal rare cause of NLDO-like agger nasi mucocele entity may facilitate timely intervention and can be treated successfully with a simultaneous endoscopic DCR procedure.

\section{BACKGROUND}

Acquired nasolacrimal duct obstruction (NLDO) may be due to various causes, including idiopathic stenosis of the nasolacrimal duct, nasolacrimal duct mucoceles, trauma or surgery to the paranasal sinuses and tumours of the nasal cavity. ${ }^{1}$ Acquired NLDO associated with an agger nasi mucocele has not been reported in the literature. On endoscopic examination, the agger nasi cell can appear as an eminence anterior to the insertion of the middle turbinate. Any disease process affecting the lateral wall of the agger nasi cell can spread to the adjacent lacrimal sac and produce epiphora. ${ }^{2}$ Initially, it is important to treat the endonasal pathology, which constitutes the cause of obstruction and then to perform a surgery in order to adress dacryocystorhinostomy (DCR). To the best of our knowledge, an isolated mucocele in an agger nasi cell has been rarely reported. ${ }^{2}$ Endonasal DCR with various methods such as laser beam emission forceps, with lateral nasal wall osteotomy, and drills, gives us the advantage to face endonasal pathology simultaneously. ${ }^{34}$

\section{CASE PRESENTATION}

A 28-year-old male patient with signs and symptoms of NLDO, presented left-sided epiphora and chronic dacryocystitis, with no history of head trauma or previous surgery of the nose or paranasal sinuses. CT and MRI imaging studies (figure 1) revealed a left-sided agger nasi mucocele and chronic rightsided sphenoid sinusitis. On nasal endoscopy, a bulging of the lateral nasal wall at the left-sided agger nasi area without any other abnormalities was noted (figure 2A). The patient had no orbital symptoms, such as visual disturbance, limited orbital movement and nasal symptoms with only left-sided epiphora. The last 5 years, he has been suffering from recurrent episodes of dacryocystitis and was initially treated with catheterisation, without the disease being resolved. Diagnosis of postsaccal NLDO was made by clinical examination, including lacrimal irrigation, fluorescein tests (Jones I and II tests), as well as probing of the canaliculi with a blunt probe up to bony contact with the lacrimal sac fossa, performed by an ophthalmologist.

\section{TREATMENT}

Under general anaesthesia, an endonasal endoscopic dacryocystorhinostomy (DCR) using a drill was performed. Through a monitor screen connected to a rigid nasal fibrotic endoscope and by using antrum curette and microdebrider, agger nasi cell was opened and a contained mucocele was removed (figure $2 \mathrm{~B}, \mathrm{C}$ ), in combination with a left anterior ethmoidectomy. There was no evidence of macroscopic erosion of the bone surrounding the mucocele. Then, intraoperative irrigation was performed by an ophthalmologist to investigate the functionality of the nasolacrimal duct (NDL). A high degree of postsaccal stenosis was still present, even after removal of the mucocele, probably due to longstanding obstruction causing formation of plug and the extensive fibrosis within the nasolacrimal sac and/or the nasolacrimal duct. After completing all endonasal procedures, left anterior ethmoidectomy and sphenoidectomy was performed. The lacrimal bone anterior to the lacrimal sac fundus was removed with cutting drill, microdebrider in association with Kerrison punch without flap (Saratziotis et al). Temporary silicone stenting of the nasolacrimal duct system was passed through both upper and lower canaliculi and fixed in the nose (figure 2E). No postoperative complications occurred (figure $2 \mathrm{~F}$ ). Oral antibiotic therapy was initiated on the day of surgery and continued for 5 days. The patient was discharged the next day.

\section{OUTCOME AND FOLLOW-UP}

Lacrimal duct system irrigation was performed by an opthalmlogist once a week during the first month, two times a month during the second month 


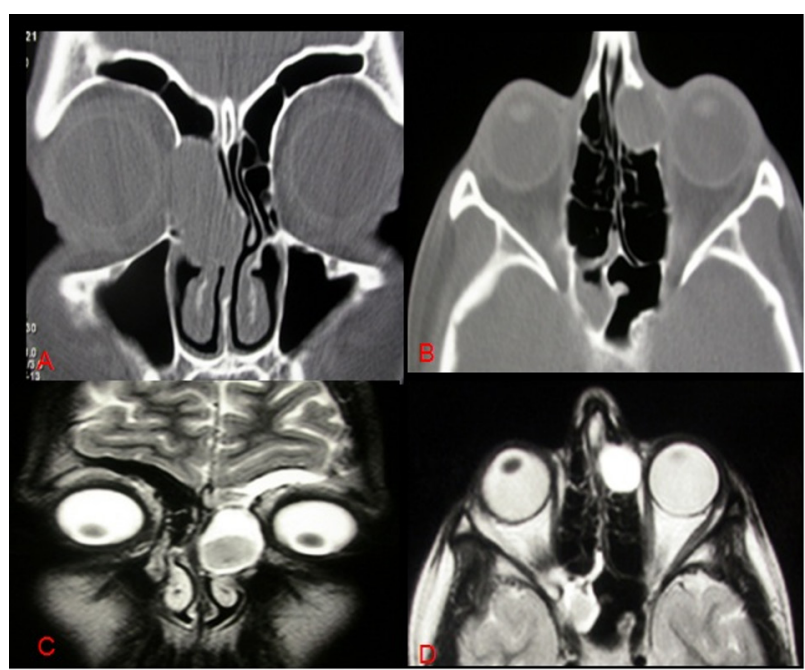

Figure 1 Paranasal sinus CT sections. (A) Height of the evaluated agger nasi in coronal section. (B) Width of evaluated agger nasi in an axial section. T2 MRI scan with gadolinium of paranasal sinus. (C) Coronal contrast enhanced. (D) Axial contrast enhanced.

and once a month during the third month postoperatively. Endoscopic endonasal examination to test the patency of the duct system was performed 15 days, 21 days and 30 days postoperatively by cleaning the operating field. Silicone stent was removed 8 weeks postoperatively. DCR window still remained functionally and anatomically patent 2 years after surgery. Improvement in tearing (epiphora), no single episode of dacryocystitis postoperatively and ability to irrigate the lacrimal system postoperatively were considered as functional success. The finding of a patent lateral nasal wall bone window on nasal endoscopy postoperatively, as well as the unobstructed intranasal flow of saline during syringing via the lacrimal puncta, was considered as anatomical success.

This cases illustrates the importance of both careful evaluation of patients with epiphora and close cooperation between ophthalmologists and Otolaryngologist (ENT) surgeons in the management of the disorders of the lacrimal system with high success rates. ${ }^{5}$

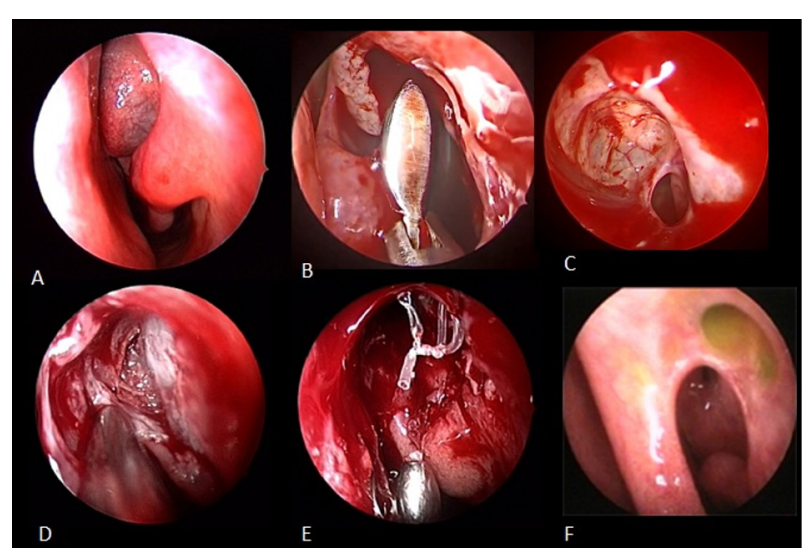

Figure 2 (A) Endoscopic endonasal localisation of the large area of the first ethmoid cell. (B) Opening cleaning and removing agger nasi cell walls. (C) Agger nasi: internal dome and wall of the (D) localisation and removal of the tear bone. (E) Performing dacryocystorhinostomy. (F) Postoperative view after 2-year follow-up.
Intranasal diseases as well as the role of anatomical variations should be included in the differential diagnosis of NLDO as in our case. Acquired NLDO caused by agger nasi mucocele was not reported in the literature before now and can be treated successfully with an endoscopic DCR procedure simultaneously.

\section{DISCUSSION}

The agger nasi is the most anterior ethmoidal air cell cell. Usually the incidence of the presence of agger nasi cells is more than $80 \%{ }^{3}$; some authors report an even higher incidence of $98.5 \%$. Furthermore, agger nasi cells are close to the lacrimal sac in 55\% of patients and should be removed during DCR surgery. ${ }^{67}$ If present, it can usually be seen on the CT scan anterior to the middle turbinate. ${ }^{8}$ Because the agger nasi cell is the key to the frontal recess, the surgical approach is to open the agger nasi cell first and establish this as the key landmark for the frontal recess dissection if necessary, and for the lateral wall in concomitance with the uncinate process. ${ }^{9}$ These anatomical structures are the key for the proper access to the nasolacrimal drainage system. ${ }^{10}$

Mucoceles are cyst-like paranasal sinus lesions lined with secretory respiratory mucosa of pseudostratified columnar epithelium. Possible causes of an agger nasi mucocele include trauma, previous surgery, chronic sinusitis or congenital abnormalities or tumours. The ethmoid and frontal sinuses are common sites of paranasal sinus mucocele development, while the maxillary and sphenoid sinuses are relatively uncommon locations. ${ }^{2}$ Given that there was no history of previous trauma, paranasal surgery or symptoms of chronic sinusitis in this patient, the cause of mucocele formation is unclear. CT scan should be considered as one of the diagnostic methods of choice.

The highest incidence occurs in the frontal sinus (60\%), followed by the ethmoid sinus (30\%) and the maxillary sinus (10\%). Sphenoid sinus mucoceles are very rare and are found in less than $1 \%$ of all cases. ${ }^{11}$ When evaluating a patient with acquired NLDO, the physician should consider evaluation for concomitant nasal and sinus disease.

There are studies that report association between radiologic evidence of sino-rhinologic disorders and lacrimal outflow obstruction and rhinologic abnormality in $87 \%$ and $63 \%$ of patients, respectively.

Their combination may also produce disease of the lateral nasal wall be the cause of dacryocystitis. ${ }^{12} 13$ There are some reports in international literature on the presence of mucocele of agger nasi, but this is the first case we know, in which it is observed to be causing epiphora, dacryocystitis and stenosis. $^{2}$

By means of an endoscopic endonasal approach, any intranasal or paranasal pathology can be treated simultaneously and a superior cosmetic result without any use of a cutaneous incision is achieved. Time to stent removal may range from 4-6 weeks to 2-3 months postoperatively. The success of DCR depends on the creation of an adequate space anterior to the common canaliculi and upper segment of the lacrimal sac, which is necessary to prevent adhesion and scarring at the site of rhinostomy. ${ }^{14}$ However, when there is a neighbouring agger nasi cell in the lacrimal bone, the endoscopic approach is indicated. ${ }^{5} 15$

Agger nasi mucocele with expansion in the lacrimal bone is a rare occurrence; however, it carries a risk of major complications (local infection, orbital cellulitis, dacryocystitis, necrosis, etc). The evolution of the mucocele can be heavy and the emergency surgery is considered as the definitive treatment. Our differential 
diagnosis of the NLDO with epiphora should consider endonasal causes also. Identification and recognition of rare etmoidal causes, like agger nasi mucocele entity, may facilitate timely intervention and can be treated successfully with a simultaneous endoscopic DCR procedure.

\section{Learning points}

- Nasoendoscopic evaluation is essential in the management of epiphora due to nasolacrimal duct obstruction, as intranasal condition such as agger nasi mucocele could be the cause.

- When the cause of epiphora is due to intranasal causes, endonasal access treatment is also indicated.

- CT scan of the head is necessary to carry out when chronic dacryocystitis with epiphora persist for a long time.

- Teamwork and close cooperation between ophthalmologists and ENT surgeons in the management of the disorders of the lacrimal system lead to high success rates.

Contributors $\mathrm{AS}, \mathrm{CZ}, \mathrm{JH}$ and $\mathrm{EE}$ contributed to planning to conception and design acquisition of data drafting the work and final approval of the version to be published.

Funding The authors have not declared a specific grant for this research from any funding agency in the public, commercial or not-for-profit sectors.

Competing interests None declared.

Patient consent for publication Obtained.

Provenance and peer review Not commissioned; externally peer reviewed.

ORCID iD

Athanasios Saratziotis http://orcid.org/0000-0002-2393-4012

\section{REFERENCES}

1 Bartley GB. Acquired lacrimal drainage obstruction: an etiologic classification system, case reports, and a review of the literature. Part 3. Ophthalmic Plast Reconstr Surg 1993;9:11-26

2 Lee J-H. Isolated Agger nasi cell mucocele. Ear Nose Throat J 2019;98:131-2.

3 Watkins LM, Janfaza P, Rubin PAD. The evolution of endonasal dacryocystorhinostomy. Surv Ophthalmol 2003;48:73-84.

4 Saratziotis A, Emanuelli E, Gouveris H, et al. Endoscopic dacryocystorhinostomy for acquired nasolacrimal duct obstruction: creating a window with a drill without use of mucosal flaps. Acta Otolaryngol 2009;129:992-5.

5 Gauba V, Islam T, Saleh GM, et al. The practice of dacryocystorhinostomy (DCR) surgery by ophthalmologists in the United Kingdom (UK). Orbit 2008;27:279-83.

6 Al-Shaikh S, Javed F, Fincham G, et al. Uk survey of the present role of ear, nose and throat surgeons in lacrimal surgery. Ann R Coll Surg Eng/ 2010;92:583-6.

7 Stammberger HR, Kennedy DW, Bolger W, Anatomic Terminology Group. Paranasal sinuses:anatomic terminology and nomenclature. Ann Otol Rhinol Laryngol Suppl 1995;167:7-16.

8 Bolger WE, Butzin CA, Parsons DS. Paranasal sinus bony anatomic variations and mucosal abnormalities: CT analysis for endoscopic sinus surgery. Laryngoscope 1991;101:56-64.

9 Wormald PJ. The Agger nasi cell: the key to understanding the anatomy of the frontal recess. Otolaryngol Head Neck Surg 2003:129:497-507.

10 Soyka MB, Treumann T, Schlegel CT. The Agger nasi cell and uncinate process, the keys to proper access to the nasolacrimal drainage system. Rhin 2010;48:364-7.

11 Arrué P, Kany MT, Serrano E, et al. Mucoceles of the paranasal sinuses: uncommon location. J Laryngol Otol 1998;112:840-4.

12 kallman JE, Foster JA, Wulc AE. Computed tomography in lacrimal outflow obstruction author links open overlay panel. Opthalmolgy 1997;104:676-82.

13 Erfanian Salim R, Mohammadi S. Results of endoscopic endonasal dacryocystorhinostomy. Necessity of Teamwork and Patient Selection Med Hypothesis Discov Innov Ophthalmol 2015:4:114-9.

14 Saratziotis A, Emanuelli E, Gouveris $\mathrm{H}$, et al. Endoscopic dacryocystorhinostomy for acquired nasolacrimal duct obstruction: long-term results in 91 procedures. Rhinology 2014;52:413-8.

15 Onerci M. Dacryocystorhinostomy. diagnosis and treatment of nasolacrimal canal obstructions. Rhinology 2002;40:49-65.

Copyright 2021 BMJ Publishing Group. All rights reserved. For permission to reuse any of this content visit

https://www.bmj.com/company/products-services/rights-and-licensing/permissions/

BMJ Case Report Fellows may re-use this article for personal use and teaching without any further permission.

Become a Fellow of BMJ Case Reports today and you can:

- Submit as many cases as you like

Enjoy fast sympathetic peer review and rapid publication of accepted articles

- Access all the published articles

Re-use any of the published material for personal use and teaching without further permission

Customer Service

If you have any further queries about your subscription, please contact our customer services team on +44 (0) 2071111105 or via email at support@bmj.com.

Visit casereports.bmj.com for more articles like this and to become a Fellow 